\title{
THE EXPRESSION OF EMOTION IN SELECTED MODERN POEMS
}

\author{
(Ekspresi Emosi dalam Puisi Moden Terpilih)
}

Nurul Afifah Adila Mohd. Salleh
afifahadila1991@gmail.com

Normaliza Abd. Rahim

drnormaliza@gmail.com

Malay Language Department, Faculty of Modern Languages and Communication, Universiti Putra Malaysia 43400 Serdang Selangor.

\begin{abstract}
Emotions may be expressed in several ways, be these verbal or non-verbal. At first, emotional reaction can be illustrated through a person's physical and cognitive development and is represented by the language in the linguistic form. This study focuses on the expression of emotion in selected modern poems. The objective of this research is to identify the types of emotions and explain the effects and influences of these emotions in modern poetry. This research was conducted employing a qualitative method to analyse the content of the text. Five modern poems from selected books were used as data. The theoretical framework of Mohd Azhar Abd Hamid (2004) which revolves around the expression of emotion was used as the basis for analysis and discussion in this study. The findings reveal that the five poems studied employ language that depicts both positive and negative emotions. This study is of great importance to writers and composers of poems, in order to ensure that what they wish to express is understood and appreciated by the listener or reader of the poems.
\end{abstract}

Keywords: expression of emotion, modern poetry, feelings, language, meaning 


\begin{abstract}
Abstrak
Ekspresi emosi seseorang boleh digambarkan menerusi beberapa cara, iaitu melalui lisan dan bukan lisan. Pada peringkat awalnya, emosi dapat digambarkan melalui reaksi fizikal seseorang kemudian berlaku perkembangan kognitif dan dilambangkan melalui bentuk linguistik, iaitu bahasa. Kajian ini memberikan fokus terhadap ekspresi emosi dalam puisi moden terpilih. Objektif kajian adalah untuk mengenal pasti jenis emosi dan menghuraikan kesan emosi dan pengaruhnya dalam puisi moden. Penyelidikan ini menggunakan kaedah kualitatif, iaitu menganalisis kandungan teks. Lima teks puisi moden daripada buku yang terpilih dijadikan bahan untuk mendapatkan data. Kerangka pemikiran Mohd Azhar Abd Hamid (2004) yang berkisar tentang ekspresi emosi akan dijadikan prinsip dalam penganalisisan dan perbincangan kajian ini. Hasil kajian mendapati bahawa, lima puisi moden tersebut menggunakan bahasa yang menggambarkan emosi sama ada emosi negatif atau positif. Kajian ini memberikan kepentingan kepada penulis puisi dan pemuisi agar apa-apa yang disampaikan dapat difahami dan dihayati oleh pendengar atau pembaca puisi tersebut.
\end{abstract}

Kata kunci: ekspresi emosi, puisi moden, perasaan, bahasa, maksud

\title{
INTRODUCTION
}

The existence of elements of emotion in a literary work is usually associated with interiority and psychology. These elements are evident in a number of cultures and as a result will seep into the literature of its people. This is to be observed not only in prose works but also in poetry. Plutchik (1970: 23 ) states that emotions are difficult to express in non-verbal ways. This is because the successful conveying of emotion depends on the word choices in a work. Studies concerning emotion are not a new phenomenon. About 2000 years ago, a Roman philosopher wrote a complete study of the emotion of anger. Several centuries later, there were widespread debates, commentaries and teachings about emotion (Averill,1982:47).

According to Mohd Azhar (2004:5), the word "emotion" comes from the Latin emover meaning move, happiness and excitement. The term "emotion" signifies subjective experiences such as love, anger, joy, shame, hate, sadness, happiness, calm and the like. Emotions also mean that the human is capable of displaying strong feelings that originate in a person's psyche, and can be instinctive depending on the situation. According to Heider (1991:6), emotion is a complicated subject to study because there 
is no exact definition that can be accepted even though emotions are part and parcel of human behaviour. Daniel (2006:12), in his turn, says that emotions will affect and influence a person's entire life experience, be it psychologically or from a social angle. Therefore, emotions are processes that have their roots in feelings and generate behaviour.

Moreover, poetry, as Coleridge famous quotations is "the best words in their best order" (Muhammad, 1993:4). Poetry is not merely beautiful in terms of language but also has great value in terms of meaning. Pradopo (1993:56) is of the opinion that poetry is aesthetic composition that has sense, meaning and is not something "empty". Poetry is a literary genre that is abstract, containing vague symbols and open to interpretation. The importance of understanding poetry is that it raises one's level of thinking and spiritual ability. The modernist poetry that emerged after 1913 went against the conventional principles of poetry in terms of number of lines, stanzas, syllables and rhyme. Such poetry attracted the attention of many and was much imitated. According to Zainal Abidin Ahmad (1965:49), modern poetry is open and consists of isometric stanzas, thus going against the conventional characteristics of poetry of, for example, traditional Malay poetic forms such as the pantun or syair. The first Malay poet to engage with modernist poetry was Omar Mustaffa, who produced a poem titled "Angan-angan dengan Gurindam", which was published in Utusan Melayu on 18 January, 1913.

\section{LITERATURE REVIEW}

In the present study, the literature review is divided into two, that is, concerning emotion and poetry. The first such related literature is a study titled "Unsur Emosi dalam Novel KOMSAS" (Elements of Emotion in Novels Studied for the Literature Component) by Faziela Abu Bakar and Nik Rafidah Nik Muhamad (2014:73). This study was carried out to identify and analyse any emotional elements expressed by three writers in three novels selected for the Malay literature component (of the secondary school syllabus in Malaysian schools). The three novels selected for the study were $6: 20$ by Siti Jasmine, Merenang Gelora (Swimming Through Stormy Waves) by Ruslan Ngah and Azfa Hanani by Azhan Mohd Hanafiah. Maslow's (1970) theory was applied in this qualitative research to analyse the textual content. The findings of this study show that seven emotions can be traced: love, happiness, shame, regret, sadness, anger and fear. These three novels concerned themselves 
mostly with the challenges that teenagers face in life at the present time, and emotions are part and parcel of teenage life. Teenagers have to learn to deal with whatever emotional experiences rationally and wisely. Amida (2005:7) has looked at vengeance in older texts. This kind of emotion should not be a part of a person's character. She is opposed in her views by Robbins (2008:24), who feels that emotions are vital motivators. With this in mind, the study by Faziela and Nik Rafidah (2014) finds, based on the novels analysed, that both positive and negative emotions are part and parcel of the human self.

Arba'ie and Nik Rafidah (2011:66) studied schoolchildren aged 7 to 12 years. The sample consisted of 30 schoolchildren from primary schools in each zone in Malaysia. The respondents were chosen at random and interviewed. Observation was also employed in order to obtain data for the specified objective. Selected children's stories were analysed using a psychostylistic approach and taking into consideration that language aspects influence the emotional development of children through literature. This study looked at how literature stimulates children's emotions. Laughter, sadness, happiness, anger, frustration, hate and the like enrich human life. Tears and the look in one's eyes are ways of displaying human emotions. Nur Ellysha Eryani (2010:45), in her study, states that literature does indeed contain elements of emotion that influence the reader or listener. Goleman (2006:6) emphasizes that one's emotional intelligence is one's ability to manage one's own and other people's emotions. Success in social life depends on one's cognitive intelligence and skill of technique.

There has been much research in the past done on poetry. Nik Fazli and Samsina (2015:33) have studied the traditional Malay poetry found in Noordin Hassan's play Bukan Lalang Ditiup Angin (Not Weeds in the Wind) (1970). This study was conducted as library research and looked at the types of Malay poetry in Bukan Lalang Ditiup Angin. The study was done using the key words conceptual theory of Mohamad Mokhtar (2001:78). The study's contribution to the literary world was that it uncovered the variety and impact of traditional Malay poetry. The unique skill and abilities of Noordin in composing traditional Malay poems has been expounded by Mana Sikana (1995), who has said that Noordin's technique is to produce poems according to rhythmic patterns. Mana Sikana (1995:84) is also of the opinion that the use of traditional forms of poetry in his dramas shows that the dramatist is extremely familiar with history. This study also revealed that the language used in Malay traditional poetry is stylistically varied 
and interesting. Noordin's poem "Kembali" (Return) (1996:11) depicts the emotion of sadness. This poem has a strong message for the community. Ali (1971:1), in defining "poetry", states that poetry is composition using language in verse form that conveys meaning. Kassim (1996:602) stresses that poetry is often used to convey a meaning in a more artistic, beautiful and euphemistic way, and suits the people who compose it.

Based on the analysis of previous research, it can be seen that most writers only focus their research on the implied meanings and language styles of the poems. The element of emotion is mainly studied in connection with novels, plays and traditional panji tales. As a result, there is a void in the research where the emotional aspect of poetry is concerned. Therefore, the present research intends to study in more detail those aspects that have to do with the psychological in poetry. Thus, this research will concern itself with the expression of emotion in modern poems, which is considered vital for writers and composers of poetry. Haslee Shahril (2003:15) states that the production of poetic works should not only consider the inner voice and the writing style of the poet but also should take into consideration the needs of the reader, i.e. what they wish to gain from a poem-whether this is realization or truth about life of just an aesthetic experience. Therefore, the ability to understand the message contained in a poem is important for a work to achieve its aim. By using language that is able to convey emotion, a reader or listener is aided to better understand and appreciate what is contained in a poem. This will, in turn, bring about a deep realization within the reader or listener of the poem (Pradopo, 1993:31).

A large number of poems written fail to have the desired effect on readers because they do not arouse the intended feeling (Aripin, 1994:14). As a result, poetry is losing its popularity and is drifting into oblivion (Normaliza and Nik Ismail, 2016). Language that expresses emotion in poetry is of great significance because it can bring about awareness and greatly influence society. Robbins (2008:16) states that emotion is of the utmost importance to motivate people in their lives. Emotion is also a common reason for people to make changes in their lives. Arba'ie and Nik Rafidah (2011:68) state that reading materials with emotional content are important for an individual's emotional development.

Because of the above issues, this research has two objectives: to identify the types of emotions, and to explain the effects of emotion in selected modern poems. 


\section{METHODOLOGY}

The texts of five modern poems were selected for this study. This research is a descriptive one using a qualitative method; the expression of emotion is evaluated through the language used in the poems. These five poems are the ones titled "Perihal Rindu"(About Longing), "Penantian" (The Wait), "Satu Nafsu Sial" (A Damned Desire), "Bintang Jatuh" (Falling Star) and "Inspirasi" (Inspiration) published by the Selut Press and Sang Freud Press. In terms of procedure for this research, issues to be researched were first identified. Subsequently, the research objectives were derived based on the research questions. Next, the research was carried out through analysis of the poems in question using the theoretical framework of Mohd Azhar (2004:3). The findings are based on the analysis carried out using the above procedure.

According to Mohd Azhar (2004:3), emotion can be divided into those that are cognitive-experiential, those that are behaviour-expressive and those that are non-verbal. For the purposes of this research, only the cognitive experiential aspect will be taken into consideration because this refers to emotions that can be expressed in words. The cognitive experiential includes both negative and positive emotions. The expression of emotion through language will be dealt with carefully in this study, and its effectiveness in modern poetry will also be studied.

The theory or theoretical framework is used as the main guideline to analyse the data since it is the distillation of ideas or views containing a set of facts that are logically related and that is interpretable for concept analysis. This study will discuss the findings according to objectives set based on the theoretical framework of Mohd Azhar (2004). The analysis and explanation of the findings of this study will be made based on the objectives outlined earlier.

According to Kasmini (1998:6), emotions are generally feelings. Emotions are important as they pattern human life. Frijda (1993:31) states that without emotions, human beings are like machines or tools that only know how to do their jobs. Therefore, emotions are feelings or reactions directed at someone. According to Muhammad Uthman (1993:42), emotions are the emergence of feelings and internal sensations, such as fear, anger, disappointment, happiness, joy or love, that are responses to something, perhaps an experience or an event that has happened. Goleman (2006:52) states the emotional intelligence refers to the ability of the self to be aware of its own and other people's emotions, apart from motivating the self, managing the emotions 


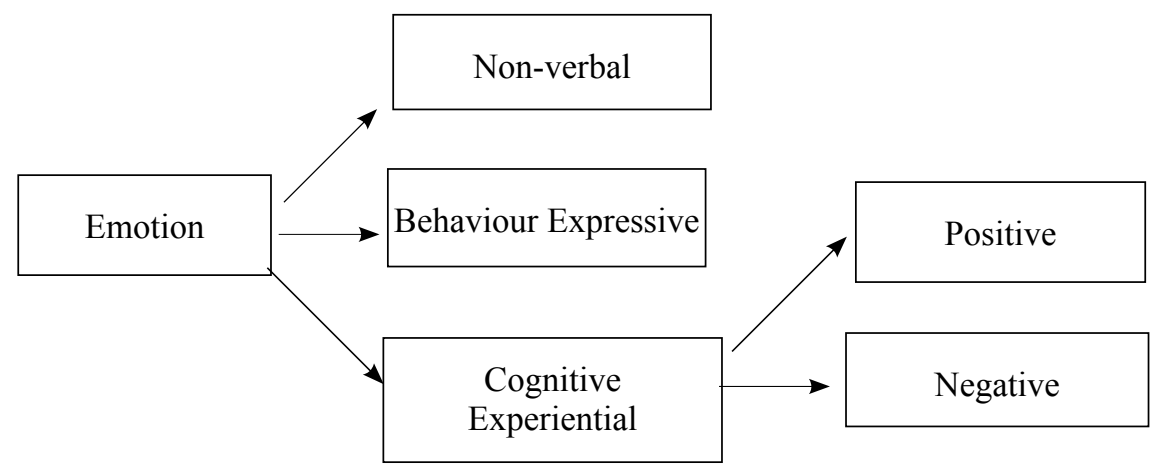

Figure 1 Summary of the division of aspects of emotion according to Mohd.

Azhar (2004).

and having good relationships with others. Emotions also influence one's decisions, creativity and attitude. In the five texts selected for this study, both positive and negative emotions were traced. Positive emotions consist of those such as longing and love while negative emotions are those such as sadness, anger and fear.

\section{FINDINGS AND DISCUSSION}

Example 1: Love

Yang membuatkan kita merasa jauh

tetap saja rindu,

Bukan jarak kau dan aku.

Dan begitulah kita, nasib akan selalu melukai kita

seperti hujan yang tajam,

tapi matahari akan tetap tiba,

tak lewat dan akan ada.

Maka ampunilah pekerjaanku,

ia menuntut waktu kita yang tak pernah cukup,

ampunilah kota yang sibuk ini,

ia sering menyembunyikan dering telefonmu yang manis.

(That which makes us feel apart

is always longing, 
Not the distance between you and me.

And that is us,

fortune will always hurt us

just like razor-sharp rain,

but the sun will always come,

never late and constant.

Therefore forgive my work,

it takes up the time of which we never have enough,

forgive this busy city,

it often conceals the sweet ringing of your call.)

(“Perihal Rindu” by Karl Agan, 2014:14.)

The poem above clearly shows elements of love expressed by one person to another. The emotion is clear through such lines as "yang membuatkan kita merasa jauh tetap saja rindu" (That which makes us feel apart is always longing). This means that the longing that engulfs the speaker in the poem shows that indeed there is love between "kau dan aku" (you and I). It can be inferred that the "kau dan aku" (you and I) in the above poem live apart as a result of their careers. The stress on the love between the two characters is continued in the lines "nasib akan selalu melukai kita/seperti hujan yang tajam/tapi matahari akan tetap tiba/tak lewat dan akan ada" (fortune will always hurt us/just like razor-sharp rain/but the sun will always come/never late and constant). The poet depicts distance as being painful; however, there is still hope because "matahari akan tetap tiba tak lewat dan akan ada" (the sun will always come, never late and constant) and the lovers will meet once again. In short, this is a poem about love between two characters, "kau dan aku" (you and I). Although they are apart and do not get to see each other all the time because they are busy with their jobs in the city, their love is constant and they believe that they will meet again at some point in time.

The love written about in the above poem is the kind of emotion that can be classified as cognitive experiential, according to Mohd Azhar's (2004) classification. Love is not limited to its existence in the human experience to love between man and woman but exists also between mother and child, father and son, and people and their country (Nur Ellysha Eryani, 2010:65). Human beings are equipped to like or love others with whom they have close ties, such as love for one's parents, children, relatives, or even possessions and other things. Possessing such an emotion is a way of ensuring everything is under control (Ab. Aziz, 1999: 31). According to Muhd Mansur 
(1986:46), a lack of love alters someone's emotional, physical, intellectual and psychological state. Without sufficient love, an individual will easily feel ostracized from others. In a prior study by Nur Ellysha Eryani (2010: 30) titled "Ekspresi Emosi dalam Cerita Panji" (The Expression of Emotion in Panji Tales), it was found that the daughter characters in the tales would feel less loved by their parents, with the result that the daughters generally considered themselves as abandoned children, or disavowing their origin, among other things. This means that emotion can be depicted by human beings through carefully selected and apt words, which in turn affect the situation. Similarly, poems that contain emotions also leave lasting effects to the extent that they may bring about some kind of realization within an individual. According to Abdullah Nashih (1996:17), love and romantic passion are human emotions. Love may include pity and sympathy but may also refer to attraction and passion. People often display their love for other people through speech or in writing.

\title{
Example 2: Disappointment
}

\author{
membunuh dari dalam \\ rasa ini \\ menyiat pelan-pelan \\ sayang ini \\ melumpuh diam-diam \\ rindu ini \\ aku dan segalaku \\ aku dan luar dalamku \\ menanti henti, meminta mati. \\ (kills from the inside \\ this feeling \\ rips slowly \\ this love \\ paralyses quietly \\ this longing \\ me and my everything \\ me and my outside inside \\ wait for the end, wish for death.]
}

["Penantian" (The Wait) by Brundage, 2014: 27] 
The poem above is a clear expression of the speaker's disappointment due to a long wait. This strong feeling of disappointment is evident in the lines "membunuh dari dalam/rasa ini/menyiat pelan-pelan/sayang ini/melumpuh diam-diam/rindu ini" (kills from the inside/this feeling/rips slowly/this love/paralyses quietly/this longing). The love and longing expressed by the speaker, which is at first very strong, begins to diminish with the long and increasingly painful wait, and the speaker is disheartened at having to wait so long for his beloved. The poem also depicts that the speaker is truly and faithfully waiting through the lines "aku dan segalaku/aku dan luar dalamku" (me and my everything/me and my outside inside), by which he means his body and soul are dedicated to living out this wait, to the extent that, as a result of the fruitless wait, he just "meminta mati" (wish(es) for death). This line suggests that he is waiting for something that has ended, that the wait is useless, which makes him feel that he just wants to die. Human beings often experience disappointment in life. In this poem, the poet successfully depicts the human emotion of disappointment. Disappointment is a cognitive experiential emotion that can be expressed in words, according to the classification of Mohd Azhar (2004:3). Disappointment is the opposite emotion of contentment or satisfaction. Therefore, in the poem above, the speaker is disappointed as he is not satisfied with the situation he is in, which is, to be waiting. Nur Ellysha Eryani (2010:57) who has studied the expression of emotion in the Panji tales states that disappointment is an emotion that is present in everyone but that most people hide their disappointment and pretend as if nothing was wrong.

\section{Example 3: Anger}

Kau pendiam, tulisan kau berbunyi simpati dan naif kau berjaya Orang pandang kau baik, orang pandang aku jahat buta-buta Tak perlu aku hebah perkara sebenar pada satu taman permainan, seperti anak kecil

Cukup aku dan tuhan saja tahu, pergi jahanam dengan yang lain

Mana kau nak cari bekas kekasih seperti aku?

Yang tak membalas fitnah dan canang buruk?

Yang keluarga kau caci dan pada rakan kau tokok cerita

namun aku masih menegur sapa dan berdoa bahagia?

(You are an introvert, your writings sound like sympathy and naivety and you manage 
To make people see you as good, and me as blindly evil

I do not need to shout out the truth in the playground

Like a small child

It is enough that God and I know, to hell with everyone else

Where will you find another lover like me?

Who doesn't respond to slander and bad report?

Who suffers your family's insults, and about whom you tell tales to your friends and yet greets you and wishes you well?)

["Satu Nafsu Sial” (A Damned Desire) by Wani Ardy, 2013: 2]

This poem depicts the emotion of anger. Sial (damned) is a word that is considered extremely rude in the Malay language, and is only used in situations of extreme anger. In this poem, the speaker [aku (I)] explains why she is very angry at kau (you). In the poem, she reveals that she has been slandered and maligned by the other person ( $k a u)$. This is seen in the lines "kau pendiam, tulisan kau berbunyi simpati dan naif kau berjaya/orang pandang kau baik, orang pandang aku jahat buta-buta" (You are an introvert, your writings sound like sympathy and naivety and you manage/To make people see you as good, and me as blindly evil). Therefore, the speaker is extremely angry with $\mathrm{kau}$. This extreme anger is further expressed through the use of the phrase pergi jahanam (go to hell). Pergi jahanam is another rude expression, a curse even, that is not normally used. The speaker is very upset at having been slandered and maligned, in the end questioning her own goodness, which does not allow her to react in a similar manner. Anger, too, is a cognitive experiential emotion according to the classification of Mohd Azhar (2004:3).

Anger is an emotion that is common in people. When it arises, it is often accompanied by physical expressions such as a red face or shaking, whereas in writing it is expressed through the type of words used (Nur Ellysha Eryani Mohd Nawi (2010:46). It has been said that heartache (physical pain of the organ) is caused by heartache (emotional pain). A person who is angry can be likened to someone secretly carrying embers. Johari Alias (1994:45) states that anger in its external appearance is the expression of emotion as a result of harbouring too much hate towards other people, towards animals or towards things that are hurtful to the self or to one's emotions. Normally, these emotions are externalized in writing or through actions such as hitting someone or something. When something happens, the concealed embers flare up into a raging fire. The anger overcomes all other instincts and emotions, and the person is no longer able to think rationally (Harun Arrasyid, 2006: 
23). Mohamed Alfian Harris and Mohamed Sharif(2001) in their study titled "Tahap Kestabilan Emosi Pelajar di Sebuah Kolej Kediaman Institusi Pengajian Tinggi Awam: Satu Tinjauan" (Emotional Stability Levels Among Students in a Public University Dorm: A Survey) found that anger is a frequently-felt human emotion. Anger is easily displayed through physical reactions and in writing. Anger that is uncontrolled by rational thinking will result in selfdestruction and the destruction of one's surroundings (Hassan, 1997:27).

\section{Example 4: Happiness}

Ku harap kau tak lupa detik malam kita menghitung bintang yang berselerak di langit tuhan di atas sana, kerna ia lebih dari sekadar bilangan malah menyimpan rahsia yang hanya milik kita.

Di kelewatan ini, hal yang mengamankan rindu yang merusuh hanyalah ingatan tentang kita di hari-hari yang telah berlarian pergi.

Dewiku, ku lihat bintang jatuh pada detik malam itu dan aku telah mendoakan keajaiban yang mustahil dalam diam, dalam sedar, dan kenangan adalah jawapan doaku yang kini tak dapat kuhindar.

(I hope that you have not forgotten that night when we counted the stars that scattered God's night sky above, because it was more than just counting numbers but the keeping of a secret that is ours alone.

At this time, the only thing that can calm the agitated longing is the memory of us in days that have rapidly left us.

My goddess, I saw a falling star that night and I prayed for an impossible miracle quietly, consciously, 
and memory is the answer to my prayer

that I cannot escape now.)

["Bintang Jatuh" (Falling Star) by Karl Agan, 2014: 67]

The above poem depicts the speakers' happiness at remembering past events that he experienced with his beloved, as is evident in "hanyalah ingatan tentang kita/di hari-hari yang telah berlarian pergi" (the memory of us/in days that have rapidly left us). The speaker is happy when remembering these past events, and this results in the longing he feels. In the first stanza, the speaker hopes that what he and his beloved have experienced will not be forgotten. Apart from this, the speaker also addresses his beloved as "Dewi" (goddess), showing his praise of her whom he misses. According to the fourth edition of Kamus Dewan, the term can be used to refer to a beautiful and influential woman. Thus, the speaker's use of the term shows that he is pleased with and full of praise for his beloved. Happiness, too, is one of the cognitive experiential emotions mentioned by Mohd Azhar (2004:3).

Happiness is an emotion that is able to make anything that we do meaningful. This is because emotions are often the catalysts to our thinking (Karl,1991:21). A positive emotion such as this one is an element that is capable of influencing the subconscious to create a habit. Everyone wishes for happiness, not one person wishes a life of sadness. When a person achieves happiness, they do not want to encounter sadness, worry or anger in their lives. However, it is the nature if things that everything is created in pairs. Thus, if there is happiness, there is also sadness. (Faziela and Nik Rafidah, 2014:82). According to Abdul Ghani, Abdul Rahman and Abdul Rashid (2007:36), happiness is something that is very good and positive. A happy person is less likely to experience imbalance compared to an unhappy one. One effect of happiness is that it can relax the body of tension. When a person is happy, they express feelings of joy and talk about things that they enjoy.

\title{
Example 5: Sadness
}

\author{
Berminggu-minggu aku teriak \\ Kau buat pekak \\ Aku perlukanmu! \\ Ada satu ruang dalam jiwa aku yang tak boleh diisi manusia, \\ walaupun dia \\ Wahai inspirasi,
}


ke mana kau pergi?

Jangan tinggalkan aku begini!

(I have been screaming for weeks

You pretend deafness

I need you!

There is a void in my soul that cannot be filled by a human being, not even him

O Inspiration,

whither have you gone?

Do not leave me like this!)

["Puisi Jalan Mati” (The Dead-End Poem) by Wani Ardy, 2013: 12]

This last example is that of a poem that concerns sadness, evident in the line "berminggu-minggu aku teriak" (I have been screaming for weeks). According to the fourth edition of Kamus Dewan (2010:54), "teriak" means "to shout" or "to scream". It can also refer to the cries one lets out during episodes of intense sadness. The poem describes how the speaker "aku" (I) is extremely sad because "kau" (you), her much-needed inspiration, has left her. The poem ends with the words "Jangan tinggalkan aku begini!" (Do not leave me like this!). This line emphasizes the extreme sadness that the speaker feels at being abandoned in her moment of need. Therefore, the poem on the whole displays a strong element of emotion. The sadness it expresses is also a cognitive experiential emotion as outlined by Mohd Azhar (2004: 3). Apart from this, words such as "teriak" and the line "Jangan tinggalkan aku begini!" are references to sadness.

Ab. Aziz (1999:18) says that sadness results when a person encounters a disappointing or upsetting situation, or from injury or pain. Sadness may cause a person to become depressed. Thus, should one encounter sadness, it is best to keep it under control. Muhammad Salleh (1994:31) says that when a person's basic needs are not met, it will cause him to suffer. This can be linked to the poem above because her wishes are not met, causing her to be sad. According to Mohd Farhan (2008:24), the main factors for causing sadness or depression are cognitive and emotional ones. Depression is a mental illness that worsens over time. Without proper care, it can have disastrous results. However, the sadness expressed in this poem is able to bring about awareness in the reader because it emphasizes the real meaning of the poem. 


\section{EFFECTS OF EMOTION AND ITS INFLUENCE ON MODERN POETRY}

Emotion has to do with feelings - the soul — and it can affect speech and actions, or anything else produced by humans. According to Mohd Daud (1990:22), emotion is an element that is fine and unique, and if we are able to use it wisely, it is of benefit to us. This is because emotion has to do with the heart. The effects of emotion on our surroundings have a deep impact on the self, depending on the type of emotion. Positive emotions bring about feelings that are good in various guises, depending on the situation, such as giving motivation, showing love, caring, praise and the like. In the present study, it is found that modern poetry has a profound emotional effect on readers. Five emotions - longing, love, sadness, anger and disappointment — are easily recognized by the reader. This is because each of the poems successfully conveys these to the reader. Arba'ie and Nik Rafidah (2011:68) state that the formation of thoughts is closely linked to emotions obtained through reading. Therefore, reading materials such as poetry should contain elements that are able to enliven them and attract the attention an interest of the reader.

Based on the analysis above, emotion plays the main part in enlivening a poem. The presence of emotion is able to increase a reader's interest in modern poetry. Because of this, emotions expressed in the poems aid readers in forming their identity and thoughts. The phenomenon of expressing emotions in poetry is not something that should dominate literature. Its presence serves to show how well a written work presents its meaning (Nur Ellysha Eryani development of the reader's ability to think and Mohd Nawi, 2010:36). Its main aim is to aid the reader's ability to think and to develop a noble character, because the reader of a poem will be affected by the work, and will obtain lessons from it.

In terms of expressions of emotion, it is clear that the modern poems studied here successfully depict and convey emotion. This can be seen in that each poem has its own elements and values through which the emotions come to the fore. The emotions that can be seen in these texts are longing, love, sadness, anger and disappointment. Muhammad Haji Salleh (1984:32) is of the opinion that poems are usually the conveyors of human experience- the ways in which people think and feel-as well as conveying the attitudes and views of a people and their world. Poetry is an expression of a person's attitudes and thoughts about something. 


\section{IMPLICATIONS OF THE STUDY}

Every study undertaken should be significant to some party in order for the study to be useful (Teeuw, 1998:11). The present study may be used as a reference or guide by poets and listeners or readers of poetry. Writers of poetry have a great responsibility in producing poetry. A poem should contain characteristics that attract readers and listeners. It is important to include elements of emotion in a poem to create a high level of awareness and understanding through the reading of such poems. Language that is able to express such emotions is extremely important to ensure that a work is presented effectively.

Past studies of emotion in literature prove that emotion is important in society. This can be gleaned from the studies carried out by Arba'ie and Nik Rafidah (2011), Faziela and Nik Rafidah (2014), as well as Nik Fazli and Samsina (2015). All three of these studies touch on emotion in the everyday life of a person and how emotions may have positive or negative effects.

\section{CONCLUSION}

This study has looked at the expression of emotion in modern poems. Emotions that are dealt with in poems could be a didactic element, that is, to point towards a better path in life. Both positive and negative emotions often influence human behaviour and have their own pros and cons.

The poems selected may have positive effects on readers or listeners in that they may increase their awareness and bring about a deeper understanding. Negative emotions can also be found in these poems, such as sadness, anger and disappointment. These serve to show that human life is never all good. Emotion in modern poetry is displayed through expressions or words that affect the reader.

This study also aids poets the uses of elements of emotion in their poetry as evident in the data analysis section. Literary works such as poems are the messages and ideas of writers that are expressed and shared with an audience. Apart from this, the question of thought, message and ideas in a literary work is the main issue that a writer should consider when producing a creative work. Poetry, as literature, has never disappeared and continues to find enthusiasts. Therefore, poetry is a strong medium for raising public awareness for any message that it may wish to convey. 


\section{REFERENCES}

Ab. Aziz Mohd Zin, 1999. Psikologi Dakwah. Kuala Lumpur: Percetakan Nasional Malaysia Berhad

Abdul Ghani Abdullah, Abdul Rahman Abdul Aziz and Abdul Rashid Mohamed, 2007. Humor dalam Pengajaran. Batu Caves: PTS Professional

Abdullah Nashih Ulwan, 1996. Pendidikan Anak dalam Islam: Pendidikan Sosial Anak. Bandung: Remaja Rosdakarya

Ali Ahmad, 1971. Asas Menganalisis Sajak. Petaling Jaya: Penerbit Fajar Bakti

Amida Abdul Hamid, 2004. Emosi Dendam dalam Kesusasteraan Melayu. Kuala Lumpur: Universiti Malaya

Arba'ie Sujud and Nik Rafidah Nik Muhamad Affendi, "Pembentukan Emosi

Kanak Kanak Melalui Bahan Bacaan Sastera" in Jurnal Pengajian Melayu, 22, pp. 66-89, 2011.

Aripin Said, 1994. Puisi Warisan. Kuala Lumpur: Dewan Bahasa dan Pustaka Averill, J. R., 1982. Anger and Aggression. Kuala Lumpur: Oxford University Press Daniel. G., 2006. Emotional Intelligence. New York: Bantan Books Faziela Abu Bakar and Nik Rafidah Nik Muhamad, "Unsur Emosi dalam Novel KOMSAS" in Jurnal Bahasa dan Sastera Melayu 5, pp.73-97, 2014.

Frijda, N. H., 1993. "Moods, Emotion Episodes and Emotions" in Lewis and Haviland (eds.). Handbook of Emotions. New York: Guilford Press.

Goleman Daniel, 2006. Kepemimpinan Berdasarkan Kecerdasan Emosi. Bandung: Gramedia Pustaka Utama.

Harun Arrasyid Haji Tuskan, 2006. Menangani Konflik Emosi According to Pandangan Islam. Selangor: Edusystem

Haslee Shahril Lim Abdullah, 2003. A Study of Malaysian School Counselor Resilience. PhD Thesis. Kuala Lumpur: Universiti Malaya

Hassan Langgulung, 1997. Asas-asas Pendidikan Islam. Kuala Lumpur: Dewan Bahasa dan Pustaka

Heider, K. G., 1991. Landscape of Emotion. New York: University of Cambridge Huntington. S. P., 1993. The Third Wave: Democratization in the Late Twentieth Century. United stated: University of Oklahoma Press

Izzard, 1977. Human Emotions. New York: Plenum Press

Johari Alias, 1994. Membina Peribadi. Kuala Lumpur: Dewan Bahasa dan Pustaka.

Kamus Dewan Bahasa dan Pustaka Edisi Kedua, 2007. Kuala Lumpur: Dewan Bahasa Dan Pustaka.

Karl Agan, 2014. Sekumpulan Epitaf dan Surat-surat yang Lewat. Shah Alam: Sang Freud Press

Kassim Ahmad, 1996. Dialog dengan Sasterawan. Kuala Lumpur: Penerbitan Pena Kasmini Kassim, 1998. Penderaan Emosi Kanak-Kanak: Trauma Terselindung. Bangi: Universiti Kebangsaan Malaysia

Mana Sikana, 1995. Drama Melayu Moden. Shah Alam: Penerbit Fajar Bakti Sdn. Bhd. 
Mohamed Alfian Harris Omar dan Mohamed Sharif Mustaffa, 2001. "Tahap Kestabilan Emosi Pelajar di Sebuah Kolej Kediaman Institusi Pengajian Tinggi Awam: Satu Tinjauan" in https://core.ac.uk/display/11776970 (capaian )

Mohd Azhar Abd Hamid, 2004. Buku EQ: Panduan Meningkatkan Kecerdasan Emosi. Kuala Lumpur: PTS Professional Publishing Sdn. Bhd.

Mohd Daud Hamzah, 1990. Emosi dalam Pembelajaran. Kuala Lumpur: Dewan Bahasa dan Pustaka

Mohd Farhan 'Uzair Bin Paisan, 2008. Tinjauan Terhadap Kemurungan dalam Kalangan Pelajar di Universiti Tun Hussein Onn. Master's Thesis. Universiti Tun Hussin Onn

Muhammad Haji Salleh, 1984. Pengalaman Puisi. Kuala Lumpur: Dewan Bahasa dan Pustaka

Muhammad Salleh Lebar, 1994. Asas Psikologi Perkembangan. Kuala Lumpur:

Utusan Publication \& Distributors Sdn. Bhd.

Muhammad Uthman Najati, 1993. Al-Quran wa Ilm Al Nafs. Kaherah: Dar al Syuruq Muhd Mansur Abdullah, 1986. Kaunseling: Teori, Proses dan Kaedah. Petaling Jaya: Penerbit Fajar Bakti Sdn. Bhd

Nadhira Brundage, 2014. Himpunan Puisi Sofa Biru. Shah Alam: Selut Press

Nik Fazli Mohamad and Samsina Abd Rahman, "Puisi-Puisi Melayu Tradisional Dalam Drama Bukan Lalang Ditiup Angin (1970) Karya Noordin Hassan" in Journal of Business and Social Development 3:1, pp. 33-42, 2015.

Normaliza Abd Rahim and Nik Ismail Harun, 2016. "Students' Perception towards Malay Folklore Songs" in Springer Science and Business. Media Singapore 2016 Regional Conference on Science Technology and Social Sciences. (RCSTSS 2014), DOI 10.1007/978-981-10-1458-1_59. 1-8

Nur Ellysha Eryani Mohd Nawi, 2010. Ekspresi Emosi dalam Cerita Panji. Master's

Thesis. Universiti Putra Malaysia

Nursalam, 2011. Manajemen Keperawatan. Edisi 3. Jakarta: Salemba Medika

Plutchik. R., 1970. Emotion, Evolution and Adaptive Processes. New York and London: Academic Press

Pradopo, R. Dj., 1993. Pengkajian Puisi. Yogyakarta: Gadjah Mada University Press Robbins, S., 2008. Perilaku Organisasi. Jakarta: Salemba Empat

Teeuw, A., 1998. Sastra dan Ilmu Sastra: Pengantar Teori Sastra. Jakarta: Pustaka Jaya Wani Ardy, 2013. Langit Vanilla. Shah Alam: Sang Freud Press

Zahir Ahmad, 2005. Emosi Melayu. Kuala Lumpur: Universit Malaya

Zainal Abidin Ahmad, 1965. Ilmu Mengarang Melayu. Kuala Lumpur: Dewan Bahasa dan Pustaka.

Received: 21 July 2016

Accepted: 21 November 2016 